\title{
The content and modelling aspect of coloratives in Japanese linguoculture
}

\author{
Irina Victorovna Shalina*, and Larisa Alexandrovna Vorobyova \\ Irkutsk State University, Department of Oriental and Asia-Pacific Studies, 664000, Irkutsk, Russia
}

\begin{abstract}
The purpose of the article is to consider Japanese coloratives as signs of the national code of linguoculture from the point of view of their content-symbolic and modeling aspects of significance. The combination of the basic coloratives of Japanese linguoculture is clarified; their pictorial, expressivepsychological, and aesthetic functions are revealed. It is established that the modeling function orients the attitude to the object of color designation in the aspect of status, prestige, and reverence. Thus, Japanese coloratives form a language system, reflecting the originality of Japanese culture and can be considered as a national code that accumulates a symbolic and simulating function, specifying and defining attitude towards objects, people, situations etc.
\end{abstract}

\section{Introduction}

Colorization, reflecting the processes of perception and conceptualization of color, represents a special phenomenon and an object of study in various directions of humanitarian knowledge, including semiotics of culture, lexicology and cognitive linguistics. Among the total physical qualities, the color is one of the most important, obvious and vivid characteristics of surrounding reality objects, which, at the same time, generates various ways to comprehend and notation of the signs of color coding - coloratives. The color coding acquires a special relevance for cultural linguistics, in which, by co-studying of language and culture, the peculiarity of the world-knowledge, the role and significance of individual world-picture fragments for a holistic national conceptosphere [5], in order to form cognitive media systems of the culture bearer, is established. The studying of the basic coloratives system of cultural linguistics allows us get closer to comprehending of holistic code of national culture based on the determination of the semiotic and axiological essence of culture. The disclosure of the cultural linguistics importance of coloratives can be carried out through the identification of the basic signs combinations, their combinatorics, and the functions of this type of signs in cultural linguistics. In this regard, it is advisable to allocate more special functions of coloratives within their meaningful, symbolic and modeling aspects of significance. As a substantially symbolic aspect of significance we mean a sustainable, conventional value of coloratives in cultural linguistics, including their lexical-semantic and actually symbolic meaning. The modeling aspect refers to the estimated value, orienting or regulating the attitude to the color coding object.

\section{Research Methods and Materials}

We used the method of analysis. Our analysis relies on scientific development in Japanese culture [6], Japanese cultural linguistics [2;3], lexicology of the Japanese language [7], Japanese coloratives [2; 3; 4]. The coloratives-signs were selected from the dictionaries of the Japanese language are presented as an analysis material [10]; the whole corpus consists of about 120 items.

\section{Problem Statement}

The purpose of our analysis is to establish a system of basic signs of Japanese coloratives and to disclose their meaningful, symbolic and modelling aspects of significance.

\section{Research Questions and Findings}

\subsection{The sign 色 iro}

The sign 色 iro 'color' should be considered as a main sign of the Japanese Coloratives. In a symbolic aspect, this colorative has the following characteristics. The sign 色 iro literally, according to its inner form, denotes the character of the color distinguishable by a person depending on the wavelength of the light. This sign is a part of the following stable expressions: 色紙 irogami 'Colored Paper' (kami means 'paper'), 色絵 iroe 'Color

Corresponding author: $\underline{\text { i_v_s2000@mail.ru }}$ 
Picture', 色 鉛 筆 iroempitsu 'Color Pencil'; it has the meaning of saturation with color 色消 L irokeshi 'Fading' (keshi is a median form of the verb of kesu 'erase'), 色があせる iro-ga aseru 'Shed', 色を失う iro-wo ushinau 'Pale', 色を抜くiro-wo nuku 'discolor'. In the modelling function, this coloratives- sign and the phraseological units formed by it are used to designate an attractive object, which is particularly clearly manifested in the fiction in order to create an image of a character and to describe love stories. It is also used in the visual function. For example, in the phraseological unit いろおんな iroonna 'Attractive Woman', where iro means 'Color', onna - 'Woman', lexeme 色 iro points to the attraction of a woman, endowing the image of a woman with charm, sexuality.

There is also an expression いろお とこ irootoko (otoko means 'Man'). It is used in relation to the lover heroes with the same connotative-assessment sense "attractive". In the explanatory dictionary of the Japanese language, this expression is interpreted as "a well-dressed beautiful young man" [10], which simulates the impression of the reader to the external image, creates an emotional and psychological background to perceive the narrative. Besides it can show the importance of the external part perceived in Japanese culture, which entered the concepts "Beauty", "Harmony", and can be evaluated by outward manifestation.

The connotative-estimated meaning of "attractiveness" is also implemented in such expressions as: 色香に迷う iroka-ni mayou 'be captivated by beauty', 色気 iroke 'attraction', 色めく iromeku 'become seductive'. Also, the sign 色 iro is used in expressions in order to describe the coquette behavior of the statement object: 色目 irome 'flirtatious look', 色目を使う iromewo tsukau 'ogle', this completely identifies one of the meanings of the sign 色 iro, namely "sensual pleasure".

\subsection{The system of Japanese color coding}

The main coloratives of the Japanese language, which make up the system of color coding, are: しろ shiro 'White', くろ kuro 'Black', あか aka 'Red', あお ao, 'Green', 'Blue', きいろ kiiro 'Yellow', みどり midori 'Green', はいろ hairo 'Gray', だいだいいろ daidaiiro 'Orange', ちゃいろ chairo 'Brown', むらさき murasaki 'Purple'. The systemic nature of this group of coloratives is displayed by: firstly, their organization around the colors "light - dark" from the evolutionary point of view; secondly, the syncreticity of some coloratives; thirdly, the combinatorics of colors among themselves while the designation of the color perception in the actual semiosis. The fact is the question of the exact composition of the main Japanese colorative system signs is debatable.

\subsubsection{The colorative 明るい akarui}

The primary Japanese color coding system was represented by two color signs - 明 ake in the meaning of 明るい akarui 'Light' and くろ kuro in the meaning of "Dark". These designations correlated with such categories as "light / dark", "lightness / darkness", creating an archetypal opposition.

Let us turn to the interpretation of the coloratives meanings, solving the problem of identifying of their sustainable "conventional-symbolic" (in a broad sense of the term) meaning according to the language system.

Following the etymological dictionary of the Japanese language [10] 明 ake is interpreted as 'obvious', 'clear', 'bright', while 暗い kurai is interpreted as 'dark', 'colorless', 'hidden', 'implicit'. This fact indicates the presence of binary oppositions "light / dark", "bright / dim", "bright / colorless", "clear / obscure".

The manifestation of the archetypal opposition in these language units suggests that they can become estimated markers, applicable in the axiological interpretation of certain conventional phenomena of different spheres of human life, showing a modeling nature of Japanese cultural linguistics bearer.

Thus, an 明 ake unit is used in expressions related to:

・ Dawn, day-spring, brightness: ひがしのそらが 明るくなってきた Higashi-no sora-ga akaruku nattekita 'The sky in the East cleared up', 夜 が 明ける yoru-ga akeru 'To dawn';

- Putting the light colors: 明るい青 akarui ao 'Light Blue';

-Clarity: 明らかにする akiraka-ni suru 'Find out', 明るみに出す akarumi-ni dasu 'Expose', 火を見るよ り明らかだ hi-wo miru yori akirakada 'It's perfectly clear';

- Expression of hope: 明日 ashita 'Tomorrow' (clear day); 明るい未来 akarui mirai 'Bright Future'; 見通し が あかるい mitooshi-ga akarui 'Excellent prospects'; 明けまして おめでとう akemashite omedetou - this phrase is used as New Year congratulation;

- Cheerful, facilitating, comfortable setting: 明るい 職場 akarui shokuba 'Excellent Workplace';

- Experience, excellent proficiency: コンピュータ 一に明るい人 kompyuuta-ni akarui hito 'A man good at computers', 人を見る 明が ある hito-wo miru meiga aru 'A penetrating man'.

\subsubsection{The colorative 暗い kurai}

The colorative 暗 $い$ kurai, in turn, is used in the following situations and expressions:

- darkness: 暗い道 kurai michi 'Dark road';

- obscurity, secrecy：暗々裏に ananri-ni 'Secret, hidden', 暗号で書く angou-de kaku 'Encrypt', 暗礁 anshou 'Pitfalls';

- putting a dark tone to the color: 暗い緑色 kurai midoriiro 'Dark green';

・ unhappy past: 暗い過去をもつ kurai kako-wo motsu 'Dark past life';

- bad mood: 暗い気持ちになる kurai kimochi-ni naru 'To become sullen'; 暗くなる kurakunaru 'To darken'; 
- being poorly informed about something: 事情に暗 い jijou-ni kurai 'Incompetent in this situation'.

As we can see from the above, the units of Japanese color system construct the opposition in every speech situation.

The opposition of light and darkness (as an archetypic) is realized in the fact that in our consciousness there was an inextricable causal relationship between the physical ability to see and acquiring knowledge, in the meaning of a clear mind and a muddy consciousness. So light always carries a positive connotation, and dark is negative.

From the point of symbolism in Japanese linguoculture, 明 ake expresses kindness, a wonderful future, full of prospects, whereas 暗い kurai - darkness, has a negative connotative character, the struggle of good and evil, light and darkness. It can also be noted that there is a nuance of expressions "light head" and "dark person", realized in a language form, as "to be skillful in something", and "not to know something".

The modelling aspect of these color meanings indicates that the Japanese believe in future, they believe that a light tomorrow will replace a dark past. However, without a dark past, it is impossible to estimate the wonderful future.

It is worth saying that this opposition regulates the formation of a color matters system in line with the "light / dark opposition". So, the light color signs include 白 shiro 'White', 赤 aka 'Red', 黄色 kiiro 'Yellow'. The dark color signs include 黒 kuro 'Black', 茶色 chairo 'Brown', 青 ao 'Blue'. Thus, we can make a conclusion that this set of coloratives is forming some field system, organizing the basic opposition 明るい/暗い akarui / kurai 'Light / Dark'.

\subsubsection{The colorative 白い shiroi}

しろい / くろい 'white - black' construct some kind of binary opposition, which plays a significant role in the axiological knowledge of the surrounding reality. These Achromatic Coloratives are originally non-valued components of color. At the same time, in a sustainable conventional connotative semantics, the meaning reflecting the sensual perception of the world in the understanding of good and evil is distinguished.

Let us turn to the colorative 白 shiro 'White'. Quite often, researchers allocate two separate prototype extensions for the "white" and "black". As a rule, quantitative adjective "white" refers to the "light", and quality adjective "white" - to the "snow". There are other prototypes, such as milk, bones and salt, etc.

However, according to the etymological dictionary of the Japanese language [https://gogene-yurai.jp/] the word in modern language, denoting the name of the color (白 shiro 'White'), did not have such a meaning in ancient times, but was understood as 'something bright', indicating rather for the presence of color, its saturation, brightness, later it expanded to the meaning of clarity. This is evidenced by the words including the colorative: 白々しい shirajirashii 'Explicit', 白状 hakujou
'Recognition, consciousness'. We can also find the definition of 白 shiro 'White' in the Japanese-Russian dictionary, and it is represented as 明るい akarui 'Bright' and 輝いている kagayaiteiru 'Shining'. Judging by the vocabulary definitions, it can be affirmed that in Japanese the most suitable example of quantitative "white" is "rays of light". While quality "white" is best presented with "snow".

In terms of the symbolic (value-modeling) content in Japanese linguistics, the sign 白 shiro 'White', expanding the sphere of representation, means innocence, unblemished reputation, purity of thoughts, cleansing, as well as the perfectness of the quality of any artifact. White paper, for example, is used only in special cases.

According to Satake Akihiro, in ancient Japanese literary compositions, the use of white color was the most frequent, applying in the description of the divine creatures clothes, considered as a symbol of light, good, purity and truth. At the same time, white color symbolizes grief, sadness. So, the white color in Japan is considered to be a mourning color, symbolizing the update, cleansing before the transition to another world. Usually the ritual of Seppuku was committed by the Japanese in white kimono. Getting ready for battle, in the samurai society it was customary to wear white robes. The readiness for death, its adoption is nothing more than the manifestation of courage and valor. Even in the words meaning the naked samurai blade the element 白 shiro is found - 白刃 hakujin. Speaking about the concept of "purity of thoughts", apparently, we are to interpret the fact that at the end of the documents it is customary to add the word 敬白 keihaku. In this context, the formula is used, obviously, to express respect, respectful appeal.

The sign 白 shiro 'White' is also associated with a general idea of the absence of color, which in the symbolic plan expands to the meaning of the absence of emotions, indifference and derogatory attitude. There are some phraseological units with this colorative: 白い目 で見る shiroi me-de miru 'Look indifferently, rolling eyes', 白眼視 hakuganshi 'Unfriendly look'. In addition, with the help of this colorative, it is possible to express some sensual perception: 白ける shirakeru 'Become mirthless', 白痴 hakuchi 'Idiocy'.

Thus, rather wide and diverse modeling aspect of the colorative 白 shiro can express the various emotional or spiritual states or the relationship to a specific object, besides it can express the absence of emotions, indifference.

\subsubsection{The colorative 黒い kuroi}

Versus White, Black color symbolizes failure, guilt and anger. Just as white, black is actively involved in meaning and designation of feelings and emotions, which can be traced in a number of phraseological units. For example, the expression 黒である kuro de aru 'Be guilty' is literally translated as "to be black", はらが 黒 い hara-ga kuroi means 'Angry' - literally "black belly". 
This directly depends on the content aspect, since the semantic of the colorative 黒 kuro 'black' correlate with the meaning 'dark', 'darkness'.

At the same time, in the semantic potential of expressions with the colorative "black", an explicit evaluation contrast is detected. Along with the negative estimated sphere, this colorative can show the ability to denote positive signs and mark positive-respectful attitude towards others. In the financial sphere, profits are marked in black, losses - in red, so, black is a sign of well-being. For example, 黒字 になる kuroji-ni naru 'Come to an active (positive) balance'.

Let us note the importance of the cultural fact that in Japan, it is customary to wear black clothes for solemn events [4], for example, to a ceremony of admission to an educational institution, or getting a new job that symbolizes some beginning. Moreover, at the end of the school year, pupils are to wear white as a symbol of completeness.

Summing up, we can say that the system cognitive opposition is manifested not only at the level of comparison of color values しろい/くろい 'white black', but also in the internal meaning of these coloratives. They consist not only of definite colors designation, but also reflect the national-cultural specifics, including the sadness and idleness, sincerity and guilt, beginning and end, death and rebirth.

\subsubsection{The colorative 赤い aka}

Let us turn to the colorative あか aka 'Red'. This color is the most popular in Japanese linguoculture. Every shade of red is considered unusually beautiful. Currently in Japanese, this color category is represented by 96 shades (紅葉色 momijiiro 'Color of reddened leaves', 赫 soho 'Slightly dark red color with a yellow tint, similar to red clay', 紅唐 benitou 'Yellowish and tart red' and so on).

In a content aspect, in its semantics, 赤 aka (defined as 赤色 akairo 'Red color'), according to Japanese linguists Nagasaki Moriteru, Yoshioka Satyo, came to the modern language from ancient times, namely from Asuka Period (飛鳥 時代, 550-710), it was formed from the stem of the word 明 ake meaning 'light' [8]. Initially, the prototype of 赤 $a k a$ was the color of the sky at dawn; it represented beauty and impeccability, which is expressed by the symbolic content of the sign. Also since ancient times, 赤 aka resembles the colors of the sun, flame and blood, it was considered as a symbol of life and for a long time it was used in a magical and ritual meaning. In chronicle "Kojiki" there is a description of the situation, when the floor was scattered with red clay to expel evil spirits. During the Edo Period, when infectious diseases, such as smallpox and measles, turned into a pandemic, people were praying for healing. They purchased the paintings named 疱瘡絵 housoue, paintings written by red ink 赤摺り akadzuri, which were setting on fire in case of person recovering [9]. Religious culture marked with red, is still alive in modern Japanese society. Red is used in various rituals.
From the point of the modeling effect, this color, firstly, relates the concept of beauty, perfection, purity, which prescribes a particularly careful attitude to it: treating it with tenderness and care. So, in Japanese, the baby is called 赤ちゃん akachan. The stem of this word is the name of the red color; it is added to the prefix of politeness and diminutive suffix. This word shows that the baby is perceived in the concept of purity, and its use prescribes a particularly affective attitude towards him. With the same symbolic semantics indicating youth and purity, the word 赤め akame is used in the meaning of 'girl'.

Secondly, the red color is also considered as an element of a talisman protecting against evil spirits. Therefore, often the gate of the temple and temple complexes are painted in red. Red, which is associated with the colors of the sun, flame and blood, is considered to be a color symbolizing life.

The red color is associated with the information concerning the prestige and place status. For example, in Japan, Tokyo University is considered very prestigious, lots of people are dreaming to enter it. Among the Japanese there is an expression 赤門にくぐる akamonni kuguru "Crawl under the Red Gate", which means the successful admission to this university, the metonymical expression "Red Gate" is used regarding the university. In other words, functionally, the color coding is used in connotation of prestigiousness and, thereby, it simulates the appropriate attitude towards the educational institution, strengthens the utilitarian-pragmatic attitude to the perception of this institution and higher education on the whole.

Thus, the third meaning of the color perception あか $a k a$ 'Red' is prestige. For example, this colorative is included into the structure of words denoting professional activities, pointing to their status. So, officials of the 5th rank are called あかき ひと akakihito 'Red Man'. It is also known that in the Edo Period, 赤本 akahon 'Red Books' with color illustrations were produced for nobility, they were containing a large number of stories in secular topics [4]. As you can see, the status content is introduced into the function of this colorative in cultural linguistics.

The fourth meaning is the same as in many other cultures, red is a modeling sign of danger. This fact is confirmed by using of such expressions as 赤信号 akashingou 'red signal', denoting danger and failure, 赤 玉 akadama 'Red Ball', denoting the approximation of the storm, which is especially important, taking into account the frequency of hazardous meteorological phenomena on the Japanese Islands and the need of the warning system for the population.

It is important to note that in counterweights to the phrase 黒字になる kuroji-ni naru 'to come to an active positive balance', expression 赤字になる akaji-ni naru 'lead to a deficit' is frequently used. So, etymologically, 赤 $a k a$ 'Red' and 黒 kuro 'black' contradict each other, forming the opposition pair "Negative / Positive".

The availability of a huge range of this color shades becomes the rationale for its multifaceted interpretation. 
We can really say that Japanese people believe in red color relevance nowadays, since the red color symbolizes protection against evil spirits. The sun on the flag of Japan is red too. As a result, it can be concluded that "red" is one of the macro signs of the Japanese cultural code.

\subsubsection{The colorative 青い ao}

Let us turn to the colorative あお (青) $a o$, the use of which in Japanese is found in the meaning of 'blue', 'light-blue', as well as 'green' [14]. In modern Japanese, in the meaning of 'green', this colorative is used only in idioms that have been preserved for a long time that indicates that there were no blue and green in Japanese linguoculture in ancient times. Green color had a syncretic character. However, while getting acquainted with the western color system, "the meaning of $a o$ has shifted into the region of blue" [1].

From the point of view of the symbolic content of these coloratives, it should be noted that 青 $a o$ in the meaning of 'green' is often used to indicate the immaturity, the youth of the object of perception. For example, to indicate the young man, the phraseological unit 青男 aootoko 'green man', 'young man' is used. This meaning is traced in a number of paremias relating to various functional areas of society. Thus, the expression 青田 買い aotagai 'buy a green field' has a meaning 'recruit a course of students'，あおだけ aodake 'green bamboo' - 'young bamboo'. In addition to the fact that 青 $a o$ is often used in the meaning of inexperience, youth, this colorative, clearly indicates the "senior-junior" hierarchy in Japanese cultural linguistics: 青二 才 aonisai 'young-green' (two-year) etc. Thus, we can see that the modeling aspect of these coloratives is to orientate the perception of objects, persons to the indulgent attitude towards elder people in the social hierarchy.

\section{Conclusion}

In a significant symbolic aspect, the coloratives are performed by cognitive, visual, expressive-emotional, aesthetic functions. The modeling aspect of the main signs of the Japanese colorative system orients the attitude to the color in the aspect of an affective or utilitarian relationship, danger, status, prestigiousness, reverence.

Linguoculturological characteristics of Japanese coloratives are disclosed through the analysis of their conventional-symbolic and axiological modal meaning. The conventional content of semantics of coloratives is detected in determining the inner form of a word showing a significant feature that motivated this nomination, as well as the components of its semantics (according to the dictionary data and semantics of phraseological units). The conventional layer of semantics also includes a steady assessment meaning. In the conditions of social culture-space, coloratives acquire a modeling character that prescribes a certain attitude, modality for the perceived and denotable object. Analysis of the main coloratives suggests that the system of coloratives, as fragments of the culture code, consists of a number of archetypal cognitive oppositions: "light / dark", "bright / dim", "clear / unclear", "new / finished", "positive / negative", "evoking emotions / staying indifferent"," visible / invisible"," personalized / impersonal". In this case, the oppositions "color / colorless" and "light/ dark" should be the main.

\section{References}

1. V. M. Alpatov Semantics of color in Japan (Moscow, 2011)

2. Yu. A. Borisova Symbols of red in Japanese and ways to transfer it to Russian (Khabarovsk, TOGU, 2017)

3. T. M. Gurevich Japanese color stereotypes and color symbols (Moscow, 2015)

4. N. A. Zavyalova Phraseological units with a colorative component as a component of the discourse of everyday life in Japan, Great Britain and Russia (Ekaterinburg, Publishing House of the Ural Institute, 2011)

5. N. B. Mechkovskaya Language Semiotics. Nature. Culture (Moscow, Academy, 2007)

6. P. A. Sadokova, I. V. Komeyev Japanese culture: a tutorial (Yuzhno-Sakhalinsk, Sakhalin State University, 2019)

7. N. Yu. Trazanova Lexicology of Japanese: Tutorial (Irkutsk, Publishing House of Irkutsk State University, 2017)

8. Nagasaki Moriteru Nihon no dentoushiki - sono shikimei to shikichyou (Tokyo, Seigenshya, 2006)

9. Yoshioka Sachio Nihon no irojiten (Tokyo, Shikoushya, 2000)

10. Kokugo jiten (Tokyo, 2001) 